\title{
Redescription of Astyanax goyacensis Eigenmann, 1908 (Ostariophysi: Characiformes: Characidae)
}

\author{
Valdener Garutti ${ }^{1}$ and Francisco Langeani ${ }^{2}$
}

Astyanax goyacensis Eigenmann, 1908 is redescribed based on the holotype and 25 topotypes. The species belongs to the $A$. bimaculatus species complex, sharing with those species a black, horizontally ovate, humeral spot (the most conspicuous feature of this complex), two diffuse vertical brown bars in the humeral area (the first through humeral spot and the second 23 scales behind), and black medium caudal-fin rays. Furthermore, A. goyacensis possesses a black stripe extending along midlateral body portion, more conspicuous in alcohol preserved specimens. These characteristics allow its inclusion in the putative "black lateral stripe" sub-group of A. bimaculatus species complex. From the species of this complex it differs by the black lateral stripe shape, pattern of chromatophores on the flank, coloration of the caudal fin, scales on the lateral line, branched rays on anal fin, eye diameter, and caudal peduncle depth. Comments about the color pattern in Astyanax bimaculatus species complex are added.

Astyanax goyacensis Eigenmann, 1908 é redescrita com base no holótipo e em 25 topótipos. Esta espécie pertence ao complexo A. bimaculatus, com o qual compartilha uma mancha umeral negra ovalada horizontalmente (a mais conspícua característica do complexo), duas barras umerais marrons difusas (a primeira passando pela umeral oval e a segunda, 2-3 escamas atrás) e raios caudais medianos negros. Além disso, A. goyacensis possui uma faixa lateral negra estendida ao longo da porção mediana do corpo, mais conspícua nos exemplares conservados em álcool. Essas características permitem incluí-la no suposto sub-grupo "faixa lateral negra" do complexo bimaculatus. Das espécies desse complexo ela difere pela forma da faixa lateral negra, padrão de cromatóforos no flanco, coloração da nadadeira caudal, escamas na linha lateral, raios ramificados na nadadeira anal, diâmetro do olho e altura do pedúnculo caudal. São adicionados comentários sobre o padrão de coloração nas espécies do complexo A. bimaculatus.

Key words: Astyanax bimaculatus species complex, Astyanax asuncionensis, Rio Vermelho, Rio Araguaia basin, Color pattern.

\section{Introduction}

Astyanax goyacensis Eigenmann, 1908 is a poorly known species, described based on a single specimen from "Goyaz", collected by "Honorio". Subsequent superficial references to the species appeared in Eigenmann (1921), who just repeated information from the original description and Géry (1977: 430) in an identification key. Therefore there is not an appropriate taxonomic characterization of $A$. goyacensis, resulting in difficult species identification. This difficulty is increasing by the fact that $A$. goyacensis belongs to the Astyanax bimaculatus species complex, a very diverse group constituted by various very similar and probably phylogenetically very close species that need to be characterized thoroughly.

Astyanax goyacensis shares with the A. bimaculatus species complex a black, horizontally ovate, humeral spot (the most conspicuous feature of the complex), and two diffuse vertical brown bars in the humeral area (the first through humeral spot and the second 2-3 scales behind). Furthermore, A. goyacensis possesses a black stripe extending along midlateral body portion, deeper along caudal-peduncle and extending through medium caudal-fin-rays, more conspicuous in alcohol preserved specimens. These characteristics allow its inclusion in the putative "black lateral stripe" sub-group of the A. bimaculatus species complex, as recognized by

\footnotetext{
${ }^{1}$ Visiting Scientist, CNPq - Universidade Federal de Mato Grosso, Instituto Universitário do Araguaia, Rodovia MT 100, Km 3.5, 78698-000 Pontal do Araguaia, Mato Grosso, Brazil. valdenergarutti@yahoo.com.br

${ }^{2}$ Universidade Estadual Paulista - UNESP, Departamento de Zoologia e Botânica, Rua Cristóvão Colombo, 2265, 15054-000 São José do Rio Preto, São Paulo, Brazil. langeani@ibilce.unesp.br
} 
Garutti (1999), which currently includes ten species (Bertaco \& Garutti, 2007): A. argyrimarginatus Garutti, 1999, A. clavitaeniatus Garutti, 2003, A. goyacensis, A. incaicus Tortonese, 1942, A. novae Eigenmann, 1911, A. rupununi Fowler, 1914, A. saltor Travassos, 1960, A. siapae Garutti, 2003, A. unitaeniatus Garutti, 1998, and A. utiariti Bertaco \& Garutti, 2007.

In recent collections in the rio Vermelho 20 topotypes of A. goyacensis were captured which, along with the holotype and the five other topotypes previously collected, compose a good series to support the redescription presented herein.

\section{Material and Methods}

The examined material is housed at the Academy of Natural Sciences of Philadelphia, Philadelphia (ANSP), Departamento de Zoologia e Botânica da Universidade Estadual Paulista, campus de São José do Rio Preto, SP (DZSJRP), Field Museum of Natural History, Chicago (FMNH), Coleção do Laboratório de Ictiologia do Instituto Universitário do Araguaia, Universidade Federal de Mato Grosso, Pontal do Araguaia (ICLMA), Museo de Biología de la Universidad Central de Venezuela, Caracas (MBUCV), Museum of Comparative Zoology, Cambridge (MCZ), Museo Escuela Politécnica Nacional, Universidad Politécnica, Quito (MEPN), Museu Nacional, Rio de Janeiro (MNRJ), Museu de Zoologia da Universidade de São Paulo, São Paulo (MZUSP), Swedish Museum of Natural History, Stockholm (NRM), and National Museum of Natural History, Smithsonian Institution, Washington (USNM). Counts and measurements follow Garutti \& Britski (1997). For meristic characters absolute frequency is presented between parentheses. Cleared and counterstained specimens (cs) are prepared according to Taylor \& Van Dyke (1985). Vertebral counts include the four vertebrae of the Weberian apparatus, and the compound caudal centrum is counted as one vertebra. Tooth counts were made in premaxillary, dentary, and maxillary bones; teeth in the left side are presented first, followed by teeth present in the right side. Values of the holotype are indicated by an asterisk.

\section{Astyanax goyacensis Eigenmann, 1908 Figs. 1-2}

Astyanax goyacensis Eigenmann, 1908: 96 (description; typelocality: Goiaz [= Brazil, Goiás State, rio Araguaia drainage, upper course of rio Vermelho at the municipality of Goiás]); -Eigenmann, 1921: 231 (identification key), 260 (copy of Eigenmann, 1908); -Géry, 1977: 430 (identification key); Garutti, 1998: 116 (list of comparative material); -Garutti, 1999: 590 (list of comparative material); -Bertaco \& Garutti, 2007: 29 (list of comparative material).

Astyanax goyazencis (error); Eigenmann, 1910: 433 (catalog).

Material examined. Holotype. MCZ 89558, 76.0 mm SL, Goyaz, Thayer Brazilian Expedition. Topotypes. Brazil, Goiás State:
MZUSP 4905, 5, 57.2-75.7 mm SL, rio Vermelho, city of Goiás (approx. 155ㅗ' 50 $00^{\circ} \mathrm{W}$ ), rio Araguaia basin, 14 Sep 1966; DZSJRP 10857, 20 (2 cs), 56.4-85.4 mm SL, rio Vermelho, about 3 km above the city of Goiás ( $15^{\circ} 55^{\prime} 11^{\prime}$ 'S 50 $07^{\circ} 51$ ”W), rio Araguaia basin, 1 Nov 2005.

Diagnosis. Astyanax goyacensis differs from all other congeners, except those belonging to the A. bimaculatus species complex (sensu Garutti, 1998), by presenting a conspicuous black humeral horizontally ovate spot, and two superficial and diffuse brown bars in the humeral area. It is distinguished from A. asuncionensis Géry, 1972 and Astyanax sp., two syntopic species from the sub-group of the Astyanax bimaculatus species complex without a black lateral stripe, by the reticulate chromatophore pattern (vs. striped in $A$. asuncionensis), the black lateral stripe (vs. absent in A. asuncionensis and Astyanax sp.), and the smaller orbital diameter, 25.5-29.8 (vs. 33.1-39.5\% HL in Astyanax sp.). From species of the bimaculatus sub-group with a black lateral stripe, it differs from A. argyrimarginatus and A. unitaeniatus by the fewer lateral line perforated scales, 35-40 (vs. $\geq 41$ ). From A. clavitaeniatus, A. novae, and A. saltor, by the smaller eye diameter, 25.5-29.8 (vs. $\geq 31.6 \%$ HL). From $A$. utiariti by the smaller eye diameter 25.5-29.8 (vs. 28.5-34.3\% HL), larger interorbital width, 37.4-48.0 (vs. 32.7-38.4\% HL), and fewer premaxillary inner row tooth cusps, four or five (vs. five to seven). Astyanax goyacensis differs from A. incaicus and $A$. rupununi by the black lateral stripe shape, continually narrowing forward (vs. abruptly narrowed forward, in a clubshaped form) (specimens in alcohol), and deeper caudalpeduncle, 11.5-14.5 (vs. 10.5-11.3\% SL and 9.1-9.2\% SL, respectively). From $A$. siapae it differs by the fewer anal-fin rays, 21-28 (vs. 28-33), smaller eye diameter, 25.5-29.8 (vs. 31.4$44.2 \% \mathrm{HL}$ ), and by the black lateral stripe shape, continually narrowing forward ( $v s$. abruptly narrowed forward, in a clubshaped form).

Description. Morphometric and meristic data presented in Table 1. Body compressed, moderately elongated. Largest body depth generally two to three scales ahead of dorsal-fin origin. Predorsal and preventral areas transversely rounded. Dorsal and ventral body portions, defined by imaginary horizontal line passing through buccal opening, unequal, dorsal shallower. Dorsal and ventral profiles asymmetric. Dorsal profile smoothly convex from snout tip to dorsal-fin origin, straight from dorsal fin to caudal-fin base, slightly concave at limits of adipose fin. Ventral profile evenly convex between snout tip and pelvic fin, straight from pelvic to anal fin, straight from anal-fin base to caudal fin. Dorsal fin origin behind first body half, its distal border straight or smoothly convex; when adpressed to body, reaching $4^{\text {th }}-5^{\text {th }}$ (males) or $8^{\text {th }}-9^{\text {th }}$ (females) scales anterior to adipose fin. Adipose-fin origin at vertical through last $4^{\text {th }}-5^{\text {th }}$ branched anal-fin rays; when adpressed to body, never surpassing vertical through tip of last anal-fin ray. Pelvic-fin origin ahead of dorsal-fin origin and middle of body; its distal border smoothly convex or straight, never reaching anal-fin 


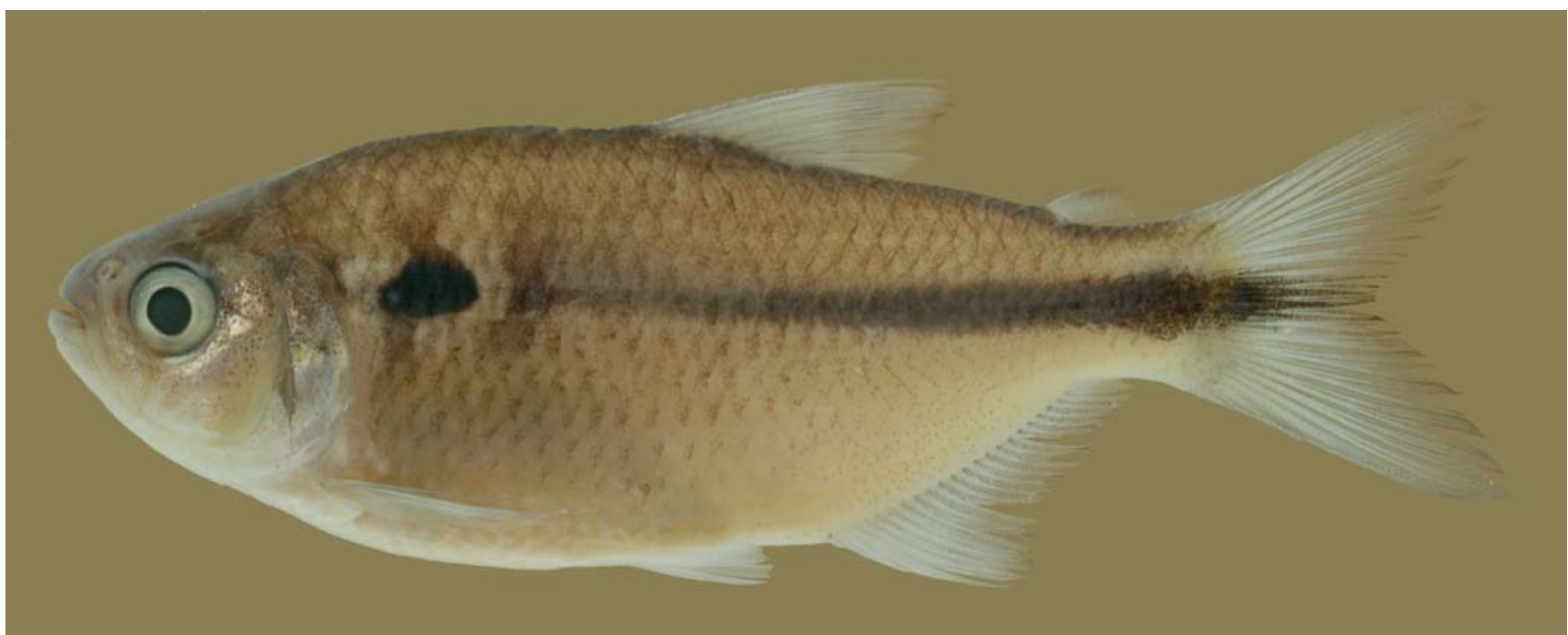

Fig. 1. Astyanax goyacensis Eigenmann, DZSJRP 10857, topotype, 75.2 mm SL, rio Vermelho, Municipality of Goiás, Goiás State, rio Araguaia basin (upon capture).

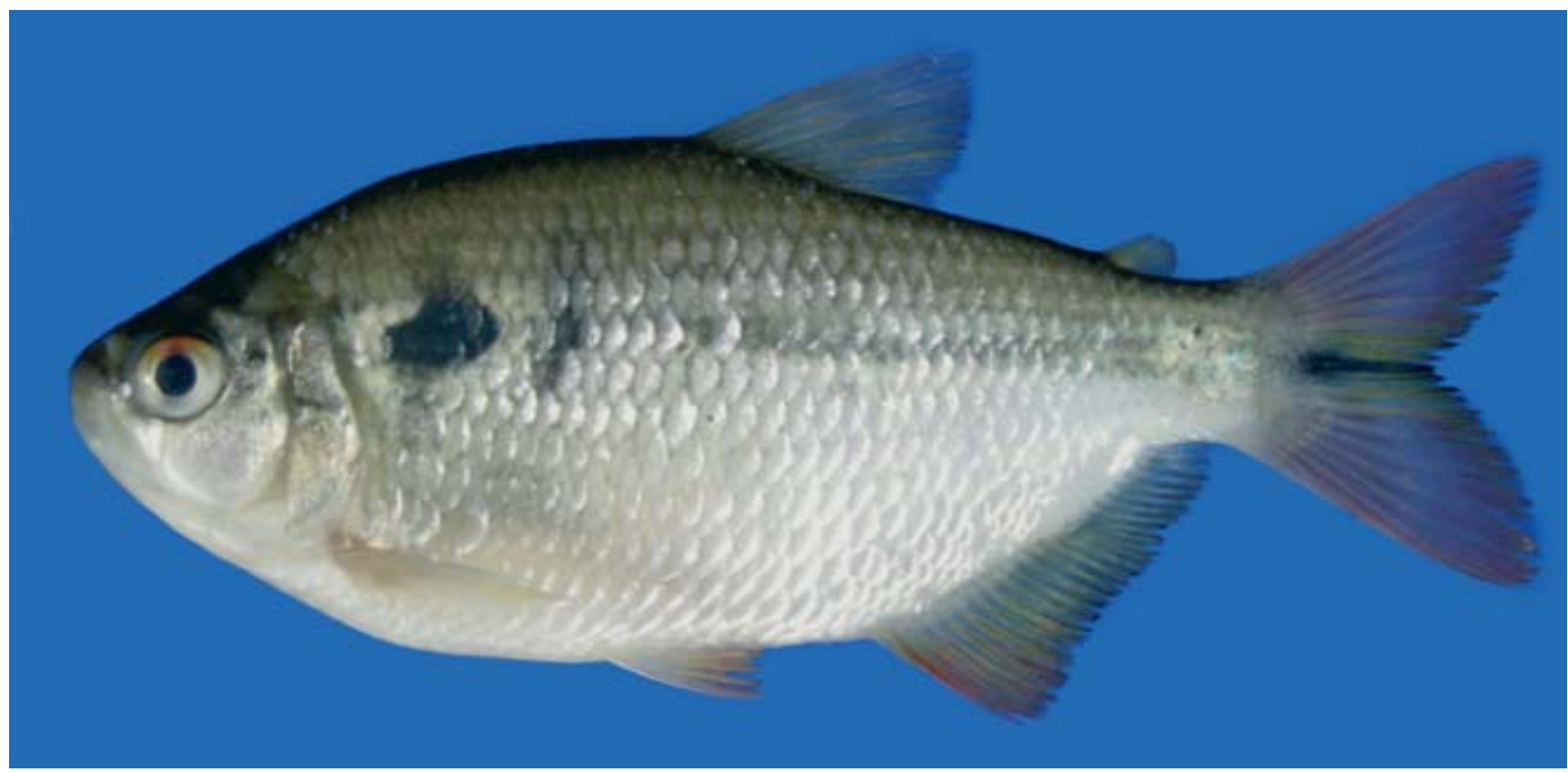

Fig. 2. Astyanax goyacensis Eigenmann, DZSJRP 10857, topotype, $57.1 \mathrm{~mm}$ SL, rio Vermelho, Municipality of Goiás, Goiás State, rio Araguaia basin (alcohol preserved specimen).

origin when adpressed to body. Anal fin origin distinctly behind dorsal-fin base, its distal border straight or smoothly concave along first third.

Pectoral fin rays i,11(5), i,12*(9) or i,13(9); pelvic fin rays i, $7 *$ (23); caudal fin i,14,i(1), i,15,i(1), or i,17,i(21); dorsal fin rays ii,8(3) or ii,9*(20); anal fin rays iii,18(1), iii,21(4), iii,22*(3), iii,23(1), iv,20(1), iv,21(8), iv,22(5), iv,23(1), iv,24(1), or v,21(1). Males with retrorse bony hooks on last unbranched and 10 first branched anal-fin rays, and along first to sixth branched pelvic-fin rays.

Head small, higher than long, moderately wide, and eye small. Mouth terminal, horizontal. Lower and upper jaws equal in length. Snout not very pointed, smaller than eye diameter. Maxillary not surpassing second infraorbital posterior margin, with almost same size of snout or smaller.

Dentary with 4 large teeth, followed by 6-8 small; large ones, tetra*, penta*, hexa, and heptacuspid; smaller teeth uni or tricuspid*. Premaxilla with two tooth-rows: inner row with 5 teeth, tetra* and pentacuspid*; outer row 3-3(1), 3-4(2), 43(1), 4-4*(13), 4-5(1), and 5-5(1) tricuspid teeth. Maxilla with $0-0(2), 1-0(1), 0-1(1)$, and $1-1 *(18)$ small uni or tricuspid* teeth.

Central cusp always larger than remaining cusps. 
Table 1. Morphometric and meristic data for Astyanax goyacensis Eigenmann, holotype (MCZ 89558) and topotypes (N: number of specimens; M: mean; SD: standard deviation).

\begin{tabular}{lcccc}
\hline \multicolumn{1}{c}{ Character } & $\mathrm{N}$ & Range & $\mathrm{M} \pm$ SD & Holotype \\
\hline Standard length (mm) & 25 & $56.4-85.4$ & 69.2 & 76.0 \\
Head length (mm) & 25 & $14.8-21.8$ & $18.1 \pm 2.0$ & 18.7 \\
Body depth (mm) & 25 & $21.1-35.2$ & $27.0 \pm 4.2$ & 27.9 \\
\multicolumn{4}{c}{ Percents of standard length } \\
Head length & 25 & $23.6-28.0$ & $26.2 \pm 1.0$ & 24.6 \\
Body depth & 25 & $35.4-46.1$ & $39.0 \pm 2.2$ & 36.7 \\
Caudal peduncle depth & 25 & $11.3-14.5$ & $12.9 \pm 0.7$ & 11.3 \\
Snout to dorsal-fin origin & 25 & $50.2-55.8$ & $53.4 \pm 1.4$ & 51.7 \\
Snout to anal-fin origin & 25 & $65.4-72.6$ & $68.9 \pm 1.8$ & 67.5 \\
Distance dorsal-pectoral fins & 25 & $40.1-48.2$ & $43.5 \pm 1.9$ & 43.2 \\
Distance dorsal-anal fins & 25 & $37.8-46.4$ & $40.2 \pm 1.8$ & 39.5 \\
Distance anal-adipose fins & 25 & $28.5-38.4$ & $36.0 \pm 2.0$ & 33.3 \\
Distance dorsal-adipose fins & 25 & $36.2-42.0$ & $39.1 \pm 1.3$ & 38.2 \\
Distance dorsal-adipose fins & 25 & $36.2-42.0$ & $39.1 \pm 1.3$ & 38.2 \\
\multicolumn{5}{c}{ Percents of head length } \\
Orbital diameter & 24 & $25.5-29.8$ & $28.3 \pm 1.0$ & 28.3 \\
Interorbital width & 25 & $37.4-48.0$ & $42.4 \pm 2.7$ & 45.5 \\
Head depth & 21 & $102.7-123.6$ & $112.2 \pm 4.9$ & 102.7 \\
\multicolumn{5}{c}{ Percents of body depth } \\
Caudal peduncle depth & 25 & $28.7-37.7$ & $33.1 \pm 2.1$ & 30.8 \\
\hline
\end{tabular}

Lateral line complete, with 35(1), 36(2), 37(8), 38*(6), 39(4), or 40(1) perforated scales. Scale rows between dorsal-fin origin and pelvic-fin origin 11(1), 12(3), 13*(11), 14(10), or 15(1), of which 5(1), 6(4), $7^{*}(19)$, or 8(2) above, and 4(1), 5*(12), or 6(13) below lateral line. One or two scale-rows covering anal-fin base.

Gill rakers $8-9+1+11-12(2)$; supraneurals $4(1)$ or $5(1)$; vertebrae 36(2); procurrent rays 11(1) and 13(1) dorsal, and 9(1) and 11(1) ventral.

Color in life. Body most silvery (Fig. 1). Head dark brown dorsally and silver laterally. Body dorsal line dark brown; flank chestnut light along four to seven scale rows above lateral line, and with reticulate chromatophore pattern (borders of scales), conspicuous and forming zigzag lines (between scale rows); flank below lateral line silvery. Gular and body ventral areas whitish. Humeral area with conspicuous black horizontal oval spot and two diffuse vertical bars. Caudal peduncle most silvery ventrally and chestnut dorsally. Dorsal fin grayish. Adipose fin slightly yellowish. Pectoral fin yellowish white. Pelvic fin whitish in proximal half and yellow to slightly orange in posterior one. Anal fin yellow-orange in first third, something blackened posteriorly. Caudal-fin medium rays black, intermediary rays yellowish, outer rays reddish. Iris with ferrugineous dorsal spot.

Color in alcohol. Body general coloration light brown with chromatophores concentrated on scale borders, forming reticulated pattern on flank, sometimes also with inconspicuous brown longitudinal lines between scale longitudinal series (Fig. 2). Head brown dorsally, light brown laterally, and silvery at opercular area. Body brown dorsally, light brown laterally, and cream ventrally. Gular area cream. Conspicuous black, horizontally oval humeral spot formed by densely grouped black chromatophores, extending horizontally from $2^{\text {nd }}$ to $6^{\text {th }}$ or $3^{\text {rd }}$ to $7^{\text {th }}$ scales on first series above lateral line, and vertically along one and half scale series above lateral line, limited by silvery areas anterior and posteriorly. Two irregular brown vertical bars on humeral region, first through humeral oval spot and second 2-3 scales behind; first bar usually six or seven scales high, and three scales wide; second bar usually five scales high, and three scales wide. Black midlateral stripe from second vertical bar to middle caudal-fin rays extremity, continually narrowing forward and backward, being less than one scale high at extremities, and two scales high at caudal peduncle. Dorsal fin membrane with numerous small dark chromatophores. Adipose fin with small, numerous and dispersed dark brown chromatophores. Pectoral fin with scattered small dark chromatophores on rays and membrane. Pelvic fin rays with scattered small dark chromatophores. Anal fin membrane with numerous small dark chromatophores. See also "Comments on the color pattern in A. bimaculatus species complex" below.

Sexual dimorphism. Mature males with sexual retrorse bony hooks on the anal-fin and pelvic-fin rays. Hooks occur on the last unbranched and up to 10 first branched anal-fin rays, and along the first to sixth branched pelvic-fin rays. Specimens captured in September, winter dry season, never presented any kind of secondary sexual dimorphism, although only five specimens have been captured and were externally examined. On the other hand, in November, at the beginning of the wet season and higher temperatures, the males presented conspicuous hooks on the anal and pelvic fins, and also fully developed gonads. Males are also shallower and smaller than females.

Habitat. The rio Vermelho at the site where A. goyacensis was captured is four meters wide and at most one meter deep. The waters were slow-flowing and turbid on November (beginning of the rainy season), and the substratum is composed of pebbles of varied sizes, coarse and fine sand, with silt and clay in smaller proportion. Relatively intact riparian forest covers the river banks. Astyanax goyacensis occurs syntopically with at least two other species of the $A$. bimaculatus species complex, A. asuncionensis and an undescribed species, which seemingly constitutes mixed schools with A. goyacensis once both were captured at the same time and in the same fishing trap.

Geographical distribution. So far known from the sub-basin of the rio Vermelho, rio Araguaia basin.

Comments on the color pattern in Astyanax bimaculatus species complex. Chromatophores in the species of the Astyanax bimaculatus complex (and probably in many other species of this genus) are distributed in at least two different levels of the integument. In the first one, more superficial, epidermic and clearly disposed above scales, chromatopores compose reticulated, striped, and dispersed patterns as showed by A. argyrimarginatus, A. goyacensis, and A. 
unitaeniatus (reticulated), A. abramis (Jenyns, 1842), A. asuncionensis, and A. maculisquamis Garutti \& Britski, 1997 (striped), and A. altiparanae Garutti \& Britski, 2000 and A. lacustris (Lütken, 1875) (dispersed). In the second level, deeper and dermic, also visible after scales removal, chromatophores compose more conspicuous and darker chromatic features such as the humeral oval spot, present in all species of the complex, the two lateral and vertical bars, commonly present also in the humeral region (the first through oval spot and the second slightly behind), and the caudalpeduncle spot or the lateral body stripe, which were used by Garutti (1999) to circumscribe respectively the "black lateral stripe" and the "caudal-peduncle spot" sub-groups in the $A$. bimaculatus species complex. The interaction among these two levels of chromatophores disposition may sometimes maximize the color features, such as the two vertical humeral bars of A. goyacensis, which are composed by chromatophores located in the epidermis and dermis.

The lateral stripe present in Astyanax argyrimarginatus, A. clavitaeniatus, A. goyacensis, A. incaicus, A. novae, A. rupununi, A. saltor, A. siapae, A. unitaeniatus, and $A$. utiariti can extend above lateral line from humeral spot, or a little behind, to the caudal peduncle and along middle caudal-fin rays; usually the lateral stripe is conspicuously deeper at the caudal peduncle in the same region of the caudal-peduncle spot. The caudal-peduncle spot, as in A. abramis, A. asuncionensis, A. altiparane, A. bimaculatus (Linnaeus, 1758), A. lacustris, and $A$. maculisquamis, usually extends along 8-10 last scales in the first row above lateral line. Furthermore, some species of the A. bimaculatus complex can also present a silvery lateral stripe, which can cover the dark lateral stripe completely, as in A. abramis (which presents a very faint dark lateral stripe, if any), or surround it dorsally and ventrally, but never the caudal-peduncle spot, as in A. argyrymarginatus.

\section{Discussion}

The original description of Astyanax goyacensis refers to the type locality as "Goyaz", with no further information about its precise geographic location. Isbrücker (1973: 174), however, on a comment about the type locality of Loricaria lata, already said "In my recent redescription of Loricaria lata (Isbrücker, 1972), I thought the Brazilian state of “Goyaz” to represent the type locality, but I overlooked to consult the map of localities in Eigenmann \& Eigenmann's work of 1890, where "Goyaz" is indicated as a place along a branch of the "Araguay” River. The type locality of Loricaria lata hence can be defined as: Brazil, Est. Goiás, Rio Araguaia drainage, upper course of Rio Vermelho at Goiás (15⒌'S 5007’ W)". Therefore and based on the new specimens referred here, we believe that the city of Goiás at the right bank of the upper rio Vermelho and the old capital of the province, is also the type locality of Astyanax goyacensis. Important to note, as stated by Lima (2004), that "the occurrence of some estuarine and marine fishes among the species supposed to have been collected at this locality, shows that at least part of the material was grossly mislabeled and that the Araguaia/Tocantins basin should not be directly admitted as being the provenience of all material labeled as “Goyaz””.

Garutti (1995) examined numerous lots and various specimens from the Araguaia-Tocantins and other South American basins, and was not able to refer to A. goyacensis outside the rio Vermelho sub-basin of the Araguaia-Tocantins basin. On the rio Vermelho, A. goyacensis occurs together with $A$. asuncionensis, based on Eigenmann (1921), who examined a lot from "Goyaz", and collected by "Honorio" (the same collector of the holotype of A. goyacensis), which specimens were considered as belonging to $A$. asuncionensis type-series, among various others from the Paraguay basin. Subsequently to Eigenmann (1921) there is no other reference to A. asuncionensis on the Araguaia-Tocantins basin. Even two other expeditions to the rio Vermelho, conducted by two different teams during the years of 1966 (MZUSP) and 2005 (V. Garutti and others), were not successful in capturing additional specimens. However, in 2005, a single specimen (ICLMA 504, $65.0 \mathrm{~mm}$ ) of A. asuncionensis was collected from the córrego Avoadeira, municipality of Barra do Garças, State of Mato Grosso, Araguaia basin, confirming the occurrence of the species in the rio Araguaia drainage.

The occurrence of hooks on the anal and pelvic fins of males is probably seasonal and related to the reproductive period, as verified by Garutti (1990) in Astyanax altiparanae and $A$. aff. fasciatus (Cuvier, 1819) and other characins fish from upper Paraná river system.

Astyanax goyacensis was referred to by Langeani et al. (2007) as occurring in the upper rio Paraná system, but based on the new findings presented here and on a reanalysis of the material from the upper Paraná, which probably belongs to a new species of the $A$. scabripinnis species complex, that reference must be now considered a wrong identification.

Comparative material. Astyanax argyrimarginatus.- MZUSP 48268, holotype, 62.3 mm SL, córrego Jaraguá, Aragarças, GO, Brazil. Astyanax asunscionensis. FMNH 54643, syntypes, 8, 21.070.7 mm SL, Asuncion, Paraguay; ICLMA 504, 1, 65.0 mm SL, Brazil, córrego Avoadeira, rio Araguaia drainage, Barra do Garças, MT, Brazil. Astyanax bimaculatus. NRM 7236, syntypes, 2, 65.278.0 mm SL, America Meridionali; USNM 225623, non-types, 37, 49.1-85.0 mm SL, Kapoeri creek, ca. 4 km from intersection with Corantijn river, Nickerie District, Surinam. Astyanax clavitaeniatus. MZUSP 5146, holotype, 48.3 mm SL, rio Surumu, Surumu, RR, Brazil. Astyanax incaicus. MEPN-RBS, non-types, 4, 63.4-97.0 $\mathrm{mm}$ SL, río Zamora, near to Zamora city, Província Zamora Chinchipe, Ecuador; MEPN-RBS-93-11, non-types, 3, 38.0-110.6 $\mathrm{mm}$ SL, beach of the río Nangaritza, Província Zamora Chinchipe, Ecuador. Astyanax novae. Type-series: FMNH 54641, 11, 24.445.4 mm SL, rio Sapão, Prazeres, BA, Brazil; FMNH 54642, 10, 27.0-67.0 mm SL, FMNH 14926, 1, 56.0 mm SL, FMNH 14927, 1, $46.3 \mathrm{~mm}$ SL, and FMNH 14928, 1, $32.8 \mathrm{~mm} \mathrm{SL}$, rio Nova, above cachoeira da Velha, TO, Brazil. Topotypes: MZUSP 68448, 6, 49.3-77.1 mm SL, and MZUSP 68454, 6, 56.8-69.7 mm SL, cachoeira da Velha, rio Nova, Ponte Alta do Tocantins, TO, Brazil. Astyanax rupununi. ANSP 39328, holotype, $47.5 \mathrm{~mm} \mathrm{SL}$, ANSP 
39329, paratype, 47.6 mm SL, Rupununi river, British Guyana. Astyanax saltor. MNRJ 9199, holotype, 43.9 mm SL, rio Cachimbo, below the waterfall, PA, Brazil. Astyanax siapae. MBUCV-V-29133, holotype, $79.5 \mathrm{~mm}$ SL, río Siapa (tributary of the río Casiquiare), Amazonas State, Venezuela. Astyanax sp. DZSJRP 11334, 9, 38.5$58.1 \mathrm{~mm}$ SL, rio Vermelho, Goiás, GO, Brazil. Astyanax unitaeniatus. MZUSP 40542, holotype, 55.9 mm SL, ribeirão Macambira, Iaciara, GO, Brazil. Astyanax utiariti. MZUSP 5177, paratypes, 6, 47.2$66.9 \mathrm{~mm}$ SL, rio Papagaio above Salto Utiariti, tributary of rio Juruena, upper rio Tapajós drainage, MT, Brazil.

\section{Acknowledgements}

To K. Hartel (MCZ), L. Palmer (USNM), P. Buckup (MNRJ), and R. Salazar (MEPN-RBS), for the loans. To S. Kullander (NRM) for providing data and photos of the type material of A. bimaculatus. To P. Vênere and I. Souza for the help with collection, and P. Vênere and M. M. F. Marinho for the A. goyacensis photos. The senior author is financially supported by the Conselho Nacional de Desenvolvimento Científico e Tecnológico-CNPq(308296/2004-4). Recent collecting permits were provided by Instituto Brasileiro do Meio Ambiente e dos Recursos Renováveis-IBAMA (068/2005-DIFAP).

\section{Literature Cited}

Bertaco, V. A. \& V. Garutti. 2007. New Astyanax from the upper rio Tapajós drainage, Central Brazil (Characiformes: Characidae). Neotropical Ichthyology, 5(1): 25-30.

Eigenmann, C. H. 1908. Zoölogical results of the Thayer Brazilian Expedition - preliminary descriptions of new genera and species of Tetragonopterid Characins. Bulletin of Museum Comparative Zoology, 2(6): 93-106.

Eigenmann, C. H. 1910. Part IV. Catalogue of the fresh-water fishes of tropical and South America. Reports of the Princeton University Expedition to Patagonia, 1896-1899, 3(3): 375-777.

Eigenmann, C. H. 1921. The American Characidae. Part 3. Memoirs of the Museum of Comparative Zoology, 43: 208-310.

Garutti, V. 1990. Caráter sexual secundário em Astyanax bimaculatus (Ostariophysi, Characidae) relacionado às nadadeiras anal e pélvicas. Naturalia, 15: 109-119.

Garutti, V. 1995. Revisão taxonômica dos Astyanax (Pisces, Characidae) com mancha umeral ovalada e mancha no pedúnculo caudal, estendendo-se à extremidade dos raios caudais medianos, das bacias do Paraná, São Francisco e Amazônica. Unpublished Thesis, IBILCE-UNESP, São José do Rio Preto, 286p.

Garutti, V. 1998. Descrição de uma espécie nova de Astyanax (Teleostei, Characidae) da bacia do Tocantins, Brasil. Iheringia, série Zoologia, 85: 115-122.

Garutti, V. 1999. Descrição de Astyanax argyrimarginatus sp. n. (Characiformes, Characidae) procedente da bacia do rio Araguaia, Brasil. Revista Brasileira de Biologia, 59(4): 585-591.

Garutti, V. \& H. A. Britski. 1997. Descrição de uma espécie nova de Astyanax (Teleostei, Characidae), com mancha umeral horizontalmente ovalada, da bacia do rio Guaporé, Amazônia. Papéis Avulsos de Zoologia, 40(14): 217-229.

Géry, J. 1977. Characoids of the World. Neptune City, NJ, THF Publications, 672p.
Isbrücker, I. J. 1973. Status of the primary homonymus South American catfish Loricaria cirrhosa Perugia, 1897, with remarks on some other loricariids (Pisces, Siluriformes, Loricariidae). Annali del Museo Civico di Storia Naturale di Genova, 79: 172-191.

Langeani, F., R. M. Castro, O. T. Oyakawa, O. A. Shibatta, C. S. Pavanelli \& L. Casatti. 2007. Ictiofauna do Alto rio Paraná: estado atual e perspectivas futuras. Biota Neotropica, 7: 1-17.

Lima, F. C. T. 2004. Brycon gouldingi, a new species from the rio Tocantins drainage, Brazil (Ostariophysi: Characiformes: Characidae), with a key for the species in the basin. Ichthyological Exploration of Freshwaters, 15(3): 279-287.

Taylor, R. \& G. C. Van Dyke. 1985. Revised procedures for staining and clearing small fishes and other vertebrates for bone and cartilage study. Cybium, 9(2): 107-119.

Accepted May 20, 2009 Published September 30, 2009 